\title{
THE OOCYTE'S NUCLEOLUS PRECURSOR BODY: THE GLOBE FOR LIFE
}

\author{
Michal Benc ${ }^{1,2}$, Lazo Pendovski ${ }^{3}$, Matej Murin ${ }^{4}$, Frantisek Strejcek ${ }^{4}$, \\ Martin Morovic ${ }^{4}$, Radek Prochazka ${ }^{5}$, Jozef Laurincik ${ }^{1,5}$ \\ ${ }^{1}$ Department of Zoology and Anthropology, Faculty of Natural Sciences, Constantine the \\ Philosopher University in Nitra, Nabrezie Mladeze 91, 94974 Nitra, Slovak Republic \\ ${ }^{2}$ Institute of Animal Science, Pratelstvi 815, 10400 Prague - Uhrineves, Czech Republic \\ ${ }^{3}$ Ss. Cyril and Methodius University in Skopje, Lazar Pop - Trajkov 5-7, \\ 1000 Skopje, Republic of Macedonia \\ ${ }^{4}$ Department of Botany and Genetics, Faculty of Natural Sciences, Constantine the \\ Philosopher University in Nitra, Nabrezie Mladeze 91, 94974 Nitra, Slovak Republic \\ ${ }^{5}$ The Czech Academy of Sciences, Institute of Animal Physiology and Genetics, \\ Rumburska 89, 27721 Libechov, Czech Republic
}

Received 28 November 2017; Received in revised form 27 January 2018; Accepted 12 February 2018

\begin{abstract}
The nucleolus is the cell organelle responsible for ribosome synthesis and, hence, for protein synthesis. In the mammalian oocyte, the nucleolus compacts into a dense sphere with no ribosome synthesis well in advance of ovulation. It seems, that this body is of utmost importance for the development of the embryo. It is unknown, however, how it exerts this essential function. During the last two decades, great attention has been paid to the study of nucleogenesis in oocytes and early embryos, with transcription of ribosomal DNA being evaluated as one of the criteria of normal development. In this review, we summarize some aspects of nucleolus transformation during oocyte growth, as well as during early embryonic development with possible impact on the quality of the embryos used in biomedical research. This knowledge in connection with further observations will substantially contribute to the development of new criteria suitable for evaluation of oocytes and embryos used in biomedical application.
\end{abstract}

Key words: nucleolus precursor body, oocyte, embryo, transcriptomics, epigenetics

\section{INTRODUCTION}

The oocyte acquires competences for sustaining embryonic development during its growth phase (1). We have demonstrated that when bovine and porcine ovarian follicles reach a diameter of about $3 \mathrm{~mm}$, the oocyte has completed its growth. At that time the nucleolus is inactivated to a sphere of

Corresponding author: M.Sc. Michal Benc

E-mail address: benc.michal@gmail.com

Present address: Drozdí chodník 5, SK-949 01 Nitra, Slovak Republic

Phone: +421915114034

Copyright: (C) 2018 Benc M. This is an open-access article published under the terms of the Creative Commons Attribution License which

permits unrestricted use, distribution, and reproduction in any medium, provided the original author and source are credited.

Competing Interests: The authors have declared that no competing interests exist.

Available Online First: 31 March 2018

Published on: 15 October 2018

https://doi.org/10.2478/macvetrev-2018-0013 densely packed material (nucleolus precursor body; NPB) and oocyte transcription ceases $(2,3)$.

We have also clearly visualized how the NPB dissolves during the final oocyte maturation and how it again assembles in the two pronuclei of the one-cell fertilized egg, the zygote (4, $5,6)$. The NPBs are anlages where functional ribosome synthesizing nucleoli develop a few cell cycles later, when transcription of the ribosomal RNA genes is activated during the major embryonic genome activation $(7,8)$. Recent studies in pig and mouse, where the oocyte's NPB was removed (enucleolation) or exchanged by micromanipulation, demonstrated that the NPB is completely essential both for completion of the oocyte's meiosis (9) and for embryonic development (10). 


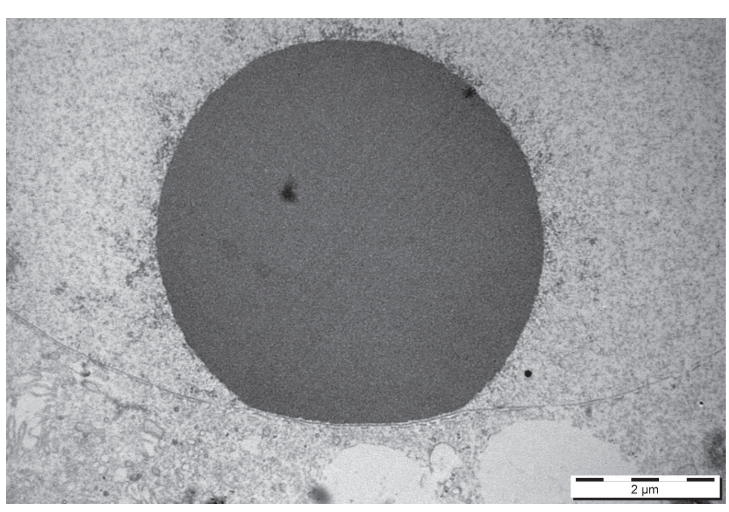

Figure 1. An electronogram of NPB in fully grown porcine oocyte. Scale bar: $2.0 \mu \mathrm{m}$

\section{The composition and the function of the nucleolus}

The typical, transcriptionally active nucleolus is composed of fibrillary centers (FC), a dense fibrillar component (DFC) and a granular component (GC) (11). This type of nucleolus is called fibrillogranullar nucleolus. It has been shown that the sub-compartments of the nucleolus host different proteins involved in transcription, processing and the assembly of pre-ribozomal units. Thus, FC and DFC contain e.g. upstream binding factor (UBF), RNA polymerase I, promotor selectivity factor (SL-1) and topoisomerase I $(12,13)$. It is well accepted that rDNA transcription occurs at the interface between the FC and the DFC (14). Consequently, the nascent rRNA is located mainly in the FC and the inner portion of the DFC, along with proteins directly involved in the early processing of the rRNA (e.g. fibrillarin). Other proteins (e.g. nucleolin and nucleophosmin) involved in the later steps of rRNA processing and formation of ribosome subunits are located in the DFC, respectively.

It has been fully accepted, for a long period of time, that the main function of the nucleolus in normal cycling cells is the biosynthesis of the ribosomes. However, recent observations in different models have shown that nucleolus is involved also in the processes regulating mitosis, cell cycle progression, proliferation, stress response, pluripotency, cellular reprogramming, etc. Therefore, it is now well accepted that the nucleolus is a multifunctional structure (15). Indeed, in yeasts and somatic cells the nucleolus, or at least material from it, is involved in cell cycle regulation with special emphasis on the transition from metaphase to anaphase (16). In yeast, inactive $\mathrm{Cdc1} 14$ (protein phosphatase) is localized in the nucleolus during the interphase, but in the anaphase Cdc14 is activated, released from the nucleolus and controls the dissolution of cohesins, a protein complex that regulates the separation of sister chromatids during mitosis and meiosis. In somatic cells, NuSAP (nucleolar-spindle associated protein) is localized in the nucleoli in the interphase, but in the M-phase it is detected in central spindle microtubules. Depletion of NuSAP results in aberrant mitotic spindles and abnormal chromosome segregation and cytokinesis.

\section{Re-organization of the nucleolus in growing oocyte and its transcriptional activity}

It was well documented that upon the activation of oocyte growth, functional nucleolus is established. However, at the end of the growth phase the nucleolus is disassembled, which associates with a gradual extrusion of fibrillar centers to the surface of the nucleolus. During this process of nucleolus re-organization, rRNA synthesis ceases and the nucleolus is, to a high degree, disassembled at the end of the oocyte growth phase $(2,17,18)$.

It has been suggested that the nucleoli of fullygrown oocytes are not involved in rRNA synthesis (8). However, in our earlier observations we were able to detect a slow but clear accumulation of $\left[5-{ }^{3} \mathrm{H}\right]$ uridine-labeled RNA (i.e. non-pre-rRNA) in NPBs of pig antral (19) and mouse preovulatory follicles (20). According to these observations it appears that most of the slowly labeled RNA, which can at least in part represent snRNAs and snoRNAs, occurs in NPB of fully grown oocytes, and that maternal nuclear RNA synthesized by the oocyte concentrates in the NPB at a higher level than elsewhere in the nucleus. However, the accumulation of slowly labeled RNA in preovulatory porcine oocytes, as observed in mouse and human (21), has not been studied so far. Moreover, it has been observed recently, that the remodeling of chromatin into the configuration observed in pre-ovulatory oocytes is not strictly required for global transcriptional repression in mammalian oocytes (22).

In addition, other results obtained in mouse indicate that the NPB might have a structural role in the transcription by other RNA polymerases than RNA polymerase I. It was shown that although the transcriptional activity of both RNA polymerase I and II decreases as the oocytes reach their full size, residual transcriptional activity can still often be found in close vicinity of the NPB in fully-grown mouse oocytes. This activity was further confirmed by RNA fluorescence in situ hybridization with a generic probe composed of non-coding sequences and indirectly, also, by the localization of the RNAbinding protein $\mathrm{Sm}$ antigen (unpublished results). The above mentioned residual transcriptional 


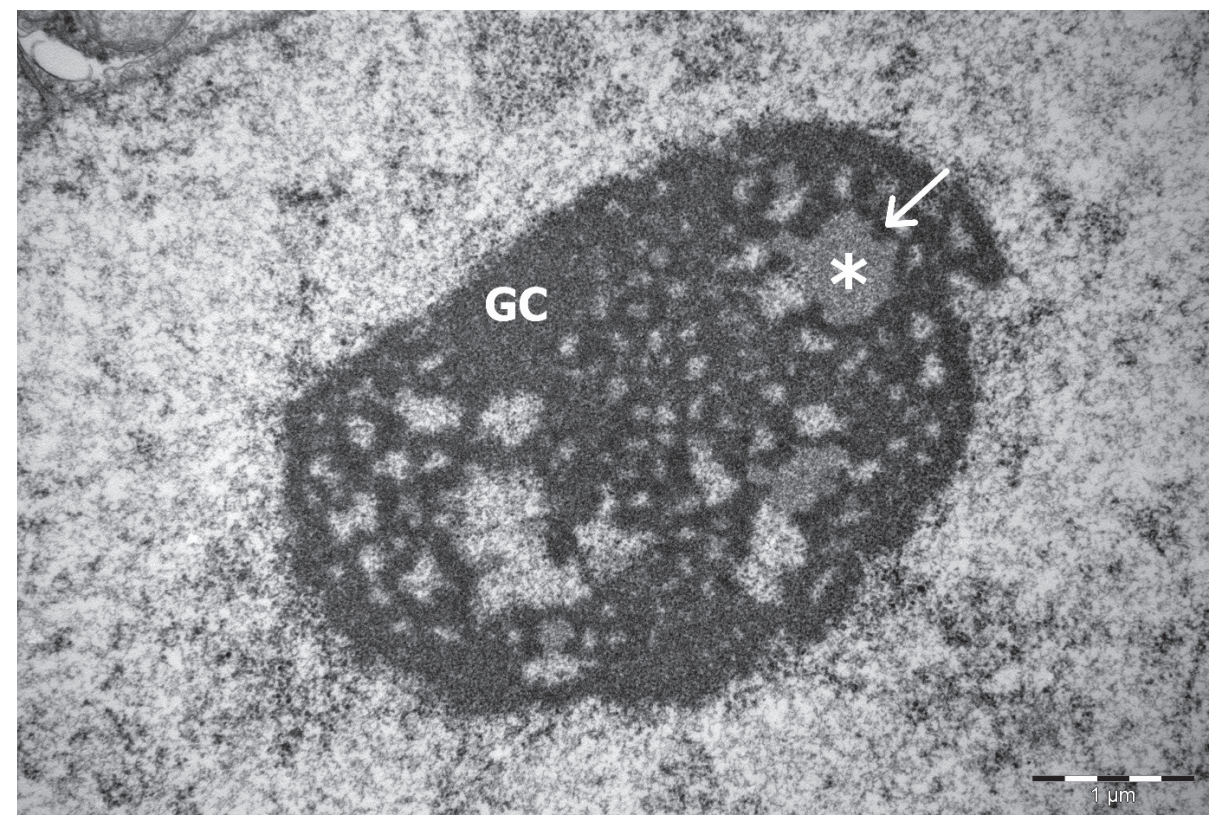

Figure 2. An electronogram of nucleolar organization in porcine embryo at the morula stage. The three nucleolar components are visible: the fibrillar centres - FC (asterisks), the dense fibrillar component - DFC (arrow), and the granular component (GC). Scale bar: $1.0 \mu \mathrm{m}$

activity was assigned to RNA polymerase I by using transcriptional inhibitor alpha-amanitin (21). However, recent results indicate that as the oocytes undergo transcriptional silencing, RNA polymerase II is redistributed and localizes namely in the vicinity of the NPB (23). Thus, these results point to the possible function of the NPB in transcriptional activity in general.

The transcriptional activity/silencing was partly studied in mouse. In this species, it was found that transcriptional silencing is brought about by extensive degradation of transcriptional machinery components (23). However, it is not clear whether such mechanism applies to oocytes of all species and thus represents a universal mechanism. Indeed, our preliminary results in porcine oocytes indicate that the mechanism might be more dependent on the phosphorylation status of the components of the transcriptional machinery. Thus, further experiments are critically needed to elucidate the mechanism of transcriptional silencing that occurs during oocyte growth and NPB formation.

The composition of the NPB and potential mechanisms for its involvement in embryonic development

In addition to the disputable requirement for the NPB to control meiotic progression and convey essential matters of life to the zygote, it is still an unresolved enigma what type of biomolecules is included in this message. In somatic cells, proteomics has demonstrated a flux of 489 endogenous nucleolar proteins in response to metabolic inhibitors (24). The authors concluded that there is no unique complete proteome for the nucleolus, but rather overlapping sets of proteomes relevant to different cell states or conditions. Further, a few candidate proteins (i.e. NPM2, NCL, SSRP1 and NOLC1) have been found in mouse oocyte NPB (25), together with other key nucleolar proteins (26). Likewise, the somatic nucleolus is rich in small RNAs including microRNAs (miRNAs) (27). Modification of rRNAs is supported by numerous small nucleolar RNAs (snoRNA) with miRNA-properties (28). However, the functional constituents in the oocyte NPB have yet to be identified.

Hours after fertilization, pronuclei appear in the zygote, and NPBs, ultrastructurally resembling the oocyte's NPB, emerge in the pronuclei (4). At a species-specific time of development, these bodies serve as anlage for the development of active ribosome synthesizing nucleoli. The NPBs, however, have multiple other functions besides being indispensable in organizing and regulating major and minor satellite repeats in the nuclei. Indeed, a recent study by Fulka et al. shows that mouse embryos obtained from enucleolated oocyte 
(i.e. after removal of the nucleolar sphere from the oocyte) were unable to achieve development beyond the 2-cell stage (10). In these embryos, ribosomal RNA (rRNA) synthesis and pre-rRNA processing were still taking, but not the transcription of the major and minor satellite repeated sequences that is known to be required for proper reorganization of pericentromeric heterochromatin and for early mouse development $(29,30)$. Moreover, absence of NPBs leads to an abnormal deposition of DAXX (an H3.3 histone chaperone) and consequently, to an abnormal remodeling of the satellite sequences. It is therefore hypothesized that NPBs should contain at least proteins involved in the proper extensive remodeling of pericentric heterochromatin that occurs during the two first cell cycles $(31,32)$. We assume that NPB could also contain (maternally inherited) RNA and proteins involved in the epigenetic mechanisms which permit proper gene expression in time and space during development.

After establishing the method of enucleolation, the field was opened again for new adventures. The method of enucleolation was described in our last review (39). The studies of Ogushi et al. (10) in pig and mouse, where the oocyte's NPBs were removed and even exchanged by micromanipulation, demonstrated that the NPB may have effects on oocyte maturation and progression of meiosis and that it certainly is crucial for embryonic development. With respect to meiosis, the first set of studies demonstrated that the NPB was not essential for progression of meiosis in the pig (10). However, later investigations by the same authors disputed this. When growing oocytes are treated by Actinomycin D, the nucleolus compacts into a NPB, and when such NPBs are exchanged with NPBs of fully grown oocytes, the latter lost the ability to progress through meiosis (9). Hence, the NPB may be involved in cell cycle control during the progression of meiosis in porcine oocytes. With respect to embryonic development, the first sets of data were clear: Oocytes that had their NPB removed did not sustain embryonic development. However, if another nucleolar sphere was transplanted to replace the lost one, embryonic developmental capacity was restored. Interestingly, if a nucleolus from a somatic cell or even an embryonic stem cell was used for the transplantation, the oocyte again did not sustain embryonic development. The latter fact indicates that the substances of the oocyte's NPB which conveys to the conceptus are not merrily nucleolar material, but other biomolecules that are crucial for the embryo to develop. Likewise, enucleated oocytes (cytoplasts) that had their NPBs removed before they underwent final maturation did not support development of cloned embryos after somatic cell nuclear transfer, whereas if nucleolar spheres were introduced into the cytoplast with the somatic cells, developmental capacity was restored. Hence, the oocyte's NPB is indeed required for conception and further life. Interestingly, later they looked into whether active ribosome synthesizing nucleoli from growing oocytes could substitute the compacted NPB in the fully grown oocyte after micromanipulatory exchange. It turned out that when active oocyte nucleoli are aspirated, chromatin remains attached to them. Transplantation of such active nucleoli were unable to sustain embryonic development, whereas transplantation of NPBs from Actinomycin D-treated oocytes (resulting in nucleolar compaction) were able to restore developmental capacity. Hence, the nucleolus develops the ability to compact into the life-giving NPB already during oocyte growth. Controversially, the same group of authors recently demonstrated that the NPB is dispensable at least in mouse embryonic development (33). If this is the case in other species as well, then this needs to be substantiated.

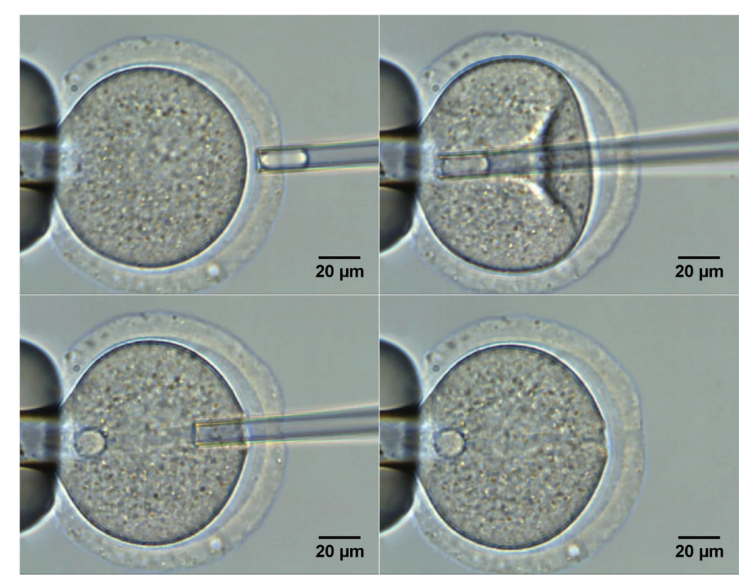

Figure 3. Nucleoli injication into the enucleolated mouse oocyte (fontot na tekstot pod slika broj 3 da e 10)

Interestingly, we have observed that the protein concentration in NPB originated from mouse oocytes is higher than in pig oocytes (34), while mouse NPBs were sufficient in securing embryonic development in the pig (35). Mouse embryos resulting from enucleolated oocytes (i.e. lacking the NPB) were unable to develop beyond the 2-cell stage (10). In such embryos, ribosomal RNA (rRNA) synthesis and prerRNA processing occurred, but transcription of sets of satellite repeats, required for proper reorganization of pericentromeric heterochromatin $(29,30)$, was lacking. Hence, we believe that the NPB contains 
The oocyte's nucleolus precursor body: the globe for life

substances involved in the epigenetic remodeling of chromatin that occurs during the first embryonic cell cycles $(25,31,32)$ and which sets the stage for proper gene expression in time and space during embryonic development. Hence, the oocyte's NPB is indeed required for conception and further life.

\section{Epigenetic changes during early embryo development}

Mammalian oogenesis, oocyte maturation and early embryo development are distinct processes, each carefully coordinated, and bound by a common thread: the need to supply an appropriately programmed genome that permits proper gene expression in time and space. In addition to transcription factors binding to promoters, regulation of transcription early in development is achieved via various epigenetic mechanisms. The epigenetic regulation occurs on the transcriptional (DNA methylation, histone modification, nucleosome positioning), as well as on the post-transcriptional level (miRNA). The interplay between these processes is crucial for maturation/ differentiation in growing oocytes, global genome silencing during the peri-fertilization period, and the determination of proper timing and the extent of dedifferentiation and embryonic genomic activation in pre-implantation embryos.

As shown previously (8), porcine preimplantation embryos do not display transcriptional activity, indicating the presence of extensive silencing marks on chromatin. The reprogramming of epigenetic memory, basic metabolic processes as well as embryonic genome activation are thus fully dependent on maternally inherited material, mRNA and rRNA, gradually being used by the embryo. However, up to now, nothing is known about the basic essential factors responsible for proper use of these RNAs. One of the most studied epigenetic modifications is DNA methylation. The level of DNA methylation of development-related genes (e.g. Oct4, Nanog, Sox2, e-cadherin, etc.) decides the silencing and/or expression of these genes and undergoes dramatic changes between oocyte maturation (hypermethylation) and early embryogenesis (hypomethylation). Moreover, the proper maintenance of parentally determined DNA methylation imprints during germ cell maturation and the postfertilization period is crucial for a proper development of concepti. Beside DNA methylation, recent data on miRNA epigenetic regulation in mouse (36) suggests that endogenous small interfering RNA (endo-siRNA) will be the key players in determining the early pre-implantation development in the porcine zygotes and embryos
(37). Together with the miRNA in the early periand postfertilization period, specific histone modifications are also responsible for successful genome activation. Histone modifications are under the control of specific histone acetyl transferases (HAT) and histone deacetylases (HDAC). The activity of these regulates the overall acquirement of gene silencing (H3K9me3, H3K27me3) and/or active marks (acH4K16, H3K4me3). Therefore, the possible aberrations in the presence and activity of these enzymes may have detrimental effect on early embryogenesis and lead to developmental arrest of embryos (38). However, if and to which extent the epigenetic changes influence an early embryonic development in embryos produced by nucleolotransfer has not been evaluated so far.

\section{CONCLUSION}

It has been shown than NPB is of utmost importance for the developmental competence of the fertilized egg and developing embryo. Hence, the nucleolar sphere contains matters that convey developmental competence to the conceptus. It is, however, unknown what this enigmatic structure contains and in what way it contributes to embryonic development. Therefore, the content of the NPB has to be analyzed by advanced molecular approaches, and the developmental competence of the NPB has to be tested by advanced micromanipulation where NPBs are transplanted from one egg to another. This will bring new knowledge about potential functions of NPB in early development of the embryos used by assisted reproductive technologies and biomedicine.

\section{CONFLICT OF INTEREST STATEMENT}

The authors declared that they have no potential conflict of interest with respect to the authorship and/or publication of this article.

\section{ACKNOWLEDGMENT}

This work was supported by Slovak Research and Development Agency under the contract No. APVV14-0001, and also by the projects CZ.02.1.01/0.0/0.0/15 _003/0000460, VEGA 1/0022/15, VEGA 1/0327/16 and Research Center AgroBioTech built in accordance with the project Building Research Centre „AgroBioTech” ITMS 26220220180. JF Jr. is supported from GACR 17-08605S. 


\section{REFERENCES}

1. Hyttel, P., Fair, T., Callesen, H., Greve, T. (1997). Oocyte growth, capacitation and final maturation in cattle. Theriogenology 47, 23-32.

https://doi.org/10.1016/S0093-691X(96)00336-6

2. Fair, T., Hyttel, P., Greve, T., Boland, M. (1996). Nucleolus structure and transcriptional activity in relation to oocyte diameter in cattle. Mol. Reprod. Dev. 43, 503-512.

https://doi.org/10.1002/(SICI)1098-2795(199604) 43:4<503::AID-MRD13>3.0.CO;2-\#

3. Bjerregaard, B., Wrenzycki, C., Philimonenko, V. V., Hozak, P., Laurincik, J., Niemann, H., Motlik, J., Maddox-Hyttel, P. (2003). Regulation of ribosomal RNA synthesis during the final phases of porcine oocyte growth. Biol. Reprod. 70, 925-935.

https://doi.org/10.1095/biolreprod.103.020941

PMid:14627545

4. Hyttel, P., Laurincik, J., Rosenkranz, C., Rath, D., Niemann, H., Ochs, R. L., Schellander, K. (2000). Nucleolar proteins and ultrastructure in preimplantation porcine embryos developed in vivo. Biol. Reprod. 63, 1848-1856.

https://doi.org/10.1095/biolreprod63.6.1848 PMid:11090457

5. Laurincik, J., Thomsen, P.D., Hay-Schmidt, A., Avery, B., Greve, T., Ochs, R. L., Hyttel, P. (2000). Nucleolar proteins and nuclear ultrastructure in pre-implantation bovine embryos produced in vitro. Biol. Reprod. 62, 1024-1032.

https://doi.org/10.1095/biolreprod62.4.1024

PMid:10727273

6. Bjerregaard, B., Wrenzycki, C., Strejcek, F., Laurincik, J., Holm, P., Ochs, R. L., Rosenkranz, C., Callesen, H., Rath, D., Niemann, H., Maddox-Hyttel, P. (2004). Expression of nucleolar related proteins in porcine preimplantation embryos produced in vivo and in vitro. Biol. Reprod. 70, 867-876. https://doi.org/10.1095/biolreprod.103.021683 PMid:14585813

7. Maddox-Hyttel, P., Bjerregaard, B., Laurincik, J. (2005). Meiosis and embryo technology: renaissance of the nucleolus. Reprod Fertil Dev. 17, 3-14.

https://doi.org/10.1071/RD04108

PMid:15745627

8. Maddox-Hyttel, P., Svarcova, O., Laurincik, J. (2007). Ribosomal RNA and nucleolar proteins from the oocyte are to some degree used for embryonic nucleolar formation in cattle and pig. Theriogenology 68, 63-70.

https://doi.org/10.1016/j.theriogenology.2007.03.015 PMid:17466364
9. Kyogoku, H., Ogushi, S., Miyano, T., Fulka, J. Jr. (2011). Nucleoli from growing oocytes inhibit the maturation of enucleolated, full-grown oocytes in the pig. Mol. Reprod. Dev. 78, 426-435.

https://doi.org/10.1002/mrd.21320

PMid:21542050

10. Ogushi, S., Palmieri, Ch., Fulka, H., Saitou, M., Miyano, T., Fulka, J. Jr. (2008). The maternal nucleolus is essential for early embryonic development in mammals, Science 319, 613-616.

https://doi.org/10.1126/science. 1151276

PMid:18239124

11. Wachtler, F., Stahl, A. (1993). The nucleolus: A structural and functional interpretation. Micron 24, 473-505.

https://doi.org/10.1016/0968-4328(93)90026-W

12. Biggiogera, M., Malatesta, M., Abolhassani-Dadras, S., Amalric, F., Rothblum, L. I., Fakan, S. (2001). Revealing the unseen: the organizer region of the nucleolus. J. Cell Sci. 114, 3199-3205. PMid:11590246

13. Koberna, K., Malinsky, J., Pliss, A., Masata, M., Vecerova, J., Fialova, M., Bednar, J., Raska, I. (2002). Ribosomal genes in focus: new transcripts label the dense fibrillar components and form clusters indicative of "Christmas trees" in situ. J. Cell. Biol. 157, 743-748.

https://doi.org/10.1083/jcb.200202007

PMid:12034768 PMCid:PMC2173423

14. Hozak, P., Cook, P. R., Schofer, C., Mosgoeller, W., Wachtler, F. (1994). Site of transcription of ribosomal RNA and intranucleolar structure in HeLa cells. J. Cell Sci. 107, 639-648.

PMid:8207086

15. Boisvert, F. M., Van Koningsbruggen, S., Navascues, J., Lamond, A. I. (2007). The multifunctional nucleolus. Nature 8, 574-585.

https://doi.org/10.1038/nrm2184

16. Fulka, H., Fulka, J. Jr. (2010). Nucleolar transplantation in oocytes and zygotes: challenges for further research. Mol. Hum. Reprod. 16, 63-67. https://doi.org/10.1093/molehr/gap088 PMid:19819895

17. Crozet, N., Motlik, J., Szollosi, D. (1981). Nucleolar fine structure and RNA synthesis in porcine oocytes during early stages of antrum formation. Biol. Cell. 41, 35-42.

18. Motlik, J., Crozet, N., Fulka, J. (1984). Meiotic competence in vitro of pig oocytes isolated from early antral follicles. J. Reprod. Fertil. 72, 323-328. https://doi.org/10.1530/jrf.0.0720323 PMid:6392543 
19. Kopecny, V., Biggiogera, M., Laurincik, J., Pivko, J., Grafenau, P., Martin, T.E., Luhrmann, R., Fu, X. D., Fakan, S. (1996). Fine structural cytochemical and immunocytochemical analysis of nucleic acids and ribonucleoprotein distribution in nuclei of pig oocytes and early preimplantation embryos. Chromosoma 104, 561-574.

https://doi.org/10.1007/BF00352296

PMid:8662249

20. Kopecny, V., Landa, V., Pavlok, A. (1995). Localization of nucleic acids in the nucleoli of oocytes and early embryos of mouse and hamster: an autoradiographic study. Mol Reprod. Dev. 41 (4): 449-458.

https://doi.org/10.1002/mrd.1080410407

PMid:7576612

21. Bouniol-Baly, C., Hamraoui, L., Guibert, J., Beaujean, N., Szollosi, M. S., Debey, P. (1999). Differential transcriptional activity associated with chromatin configuration in fully grown mouse germinal vesicle oocytes. Biol. Reprod. 60, 580-587. https://doi.org/10.1095/biolreprod60.3.580 PMid:10026102

22. De La Fuente, R. (2006). Chromatin modifications in the germinal vesicle $(\mathrm{GV})$ of mammalian oocytes. Dev. Biol. 292, 1-12.

https://doi.org/10.1016/j.ydbio.2006.01.008 PMid:16466710

23. Fulka, H., Novakova, Z., Mosko, T., Fulka, J. Jr. (2009). The inability of fully grown germinal vesicle stage oocyte cytoplasm to transcriptionally silence transferred transcribing nuclei. Histochem Cell Biol. 132, 457-468.

https://doi.org/10.1007/s00418-009-0625-x

PMid:19649647

24. Andersen, J. S., Lam, Y. W., Leung, A. K. L., Ong, S., Lyon, C. E., Lamond, A. I., Mann, M. (2005). Nucleolar proteome dynamics. Nature 433, 77-82. https://doi.org/10.1038/nature03207 PMid:15635413

25. Ogushi, S., Yamagata, K., Obuse, C., Furuta, K., Wakayama, T., Matzuk, M. M., Saitou, M. (2017). Reconstitution of the oocyte nucleolus in mice through a single nucleolar protein, NPM2. J Cell Sci. 130, 2416-2429.

https://doi.org/10.1242/jcs. 195875

PMid:28600324

26. Shishova, K. V., Lavrentyeva, E. A., Dobrucki, J. W., Zatsepina, O. V. (2015). Nucleolus-like bodies of fully-grown mouse oocytes contain key nucleolar proteins but are impoverished for rRNA. Dev. Biol. 397, 267-281.

https://doi.org/10.1016/j.ydbio.2014.11.022

PMid:25481757
27. Bai, B., Liu, H., Laiho, M. (2014). Small RNA expression and deep sequencing analyses of the nucleolus reveal the presence of nucleolus-associated microRNAs. FEBS Open Bio. 4, 441-449. https://doi.org/10.1016/j.fob.2014.04.010 PMid:24918059 PMCid:PMC4050192

28. Bai, B., Yegnasubramanian, S., Wheelan, S. J., Laiho, M. (2014). RNA-Seq of the nucleolus reveals abundant SNORD44-derived small RNAs. PLoS One. 9(9): e107519. doi: 10.1371/journal. pone.0107519. eCollection

https://doi.org/10.1371/journal.pone.0107519

29. Probst, A. V., Okamoto, I., Casanova, M., El Marjou, F., Le Baccon, P., Almouzni, G. (2010). A strandspecific burst in transcription of pericentric satellites is required for chromocenter formation and early mouse development. Dev. Cell. 19, 625-638.

https://doi.org/10.1016/j.devcel.2010.09.002 PMid:20951352

30. Casanova, M., Pasternak, M., El Marjou, F., Le Baccon, P., Probst, A. V., Almouzni, G. (2013). Heterochromatin reorganization during early mouse development requires a single-stranded noncoding transcript. Cell Rep. 26, 1156-1167. https://doi.org/10.1016/j.celrep.2013.08.015 PMid:24055057

31. Santenard, A., Ziegler-Birling, C., Koch, M., Tora, L., Bannister, A. J., Torres-Padilla, M.E. (2010). Heterochromatin formation in the mouse embryo requires critical residues of the histone variant H3.3. Nat. Cell Biol. 12, 853-862.

https://doi.org/10.1038/ncb2089

PMid:20676102 PMCid:PMC3701880

32. Aguirre-Lavin, T., Adenot, P., Bonnet-Garnier, A., Lehmann, G., Fleurot, R., Boulesteix, C., Debey, P., Beaujean, N. (2012). 3D-FISH analysis of embryonic nuclei in mouse highlights several abrupt changes of nuclear organization during preimplantation development. BMC Dev. Biol. 12, 12-30. https://doi.org/10.1186/1471-213X-12-30 PMid:23095683 PMCid:PMC3517311

33. Kyogoku, H., Fulka, J. Jr., Wakayama, T., Miyano, T. (2014). De novo formation of nucleoli in developing mouse embryos originating from enucleolated zygotes. Development 141, 2255-2259.

https://doi.org/10.1242/dev.106948 PMid:24803589

34. Morovic, M., Strejcek, F., Fulka Jr., J., Hyttel, P., Laurincik, J. (2014). Proteomic disproportion of nucleoli in pig and mouse fully grown oocytes. European Biotechnology Congress 2014, J. Biotech., 185, Supplement, September 2014, Page 46. https://doi.org/10.1016/j.jbiotec.2014.07.155 
35. Morovic, M., Strejcek, F., Nakagawa, S., Deshmukh, R. S., Murin, M., Benc, M., Fulka, H., Kyogoku, H., Pendovski, L., Fulka, J., Jr., Laurincik, J. (2017). Mouse oocytes nucleoli rescue embryonic development of porcine enucleolated oocytes, Zygote ahead of print.

36. Suh, N., Baehner, L., Moltzahn, F., Melton, C., Shenoy, A., Chen, J., Blelloch, R. (2010). MicroRNA function is globally suppressed in mouse oocytes and early embryos. Current Biol. 20, 271-277. https://doi.org/10.1016/j.cub.2009.12.044 PMid:20116247 PMCid:PMC2872512

37. Li, M., Xia, Y., Gu, Y., Zhang, K., Lang, Q., Chen, L., Guan, J., Luo, Z., Chen, H., Li, Y., Li, Q., Li, X., Jian, A., Shuai, S., Wang, J., Zhu, Q., Zhou, X., Gao, X., Li, X. (2010). MicroRNAome of porcine pre-and postnatal development. PLOS one 5:e11541.

https://doi.org/10.1371/journal.pone.0011541

PMid:20634961 PMCid:PMC2902522
38. Niemann, H., Tina, X. C, King, E. A., Lee, R. S. F. (2008). Epigenetic reprogramming in embryonic and foetal development upon somatic cell nuclear transfer cloning. Reproduction 135, 151-163.

https://doi.org/10.1530/REP-07-0397

PMid:18239046

39. Benc, M., Strejcek, F., Murin, M., Morovic, M., Martinkova, S., Jettmarova, D., Pendovski, L., Fulka, J. Jr., Laurincik, J. (2017). Nucleologenesis and nucleolotransfer in mammalian oocytes: A review. Mac Vet Rev. 40 (2): 117-124.

https://doi.org/10.1515/macvetrev-2017-0023

Please cite this article as: Benc M., Pendovski L., Murin M., Strejcek F., Morovic M., Prochazka R., Laurincik J. The oocyte's nucleolus precursor body: the globe for life. Maced Vet Rev 2018; 41 (2): 115-122. https://doi.org/10.2478/macvetrev-2018-0013 